\title{
Honeybees and Pollen as Indicators of Alien Plant Species in Two Native Forest Ecosystems of an Oceanic Island (La Palma, Canary Islands)
}

\author{
Lea de Nascimento ${ }^{*}, 1$ Juan D. Delgado ${ }^{2}$, Javier Méndez ${ }^{1}$, Rüdiger Otto ${ }^{1}$, Manuel Arteaga ${ }^{1}$ and \\ José M. Fernández-Palacios ${ }^{1}$
}

\author{
${ }^{I}$ Departmento de Ecología, Facultad de Biología, Universidad de La Laguna, 38206, La Laguna, Spain \\ ${ }^{2}$ Área de Ecología, Departamento de Sistemas Físicos, Químicos y Naturales, Universidad Pablo de Olavide, 41013, \\ Sevilla, Spain
}

\begin{abstract}
Apis mellifera L. is a generalist pollinator present in most of the Canary Islands. When foraging, honeybees transfer pollen grains to honey, and presence and abundance of pollen from different species can be interpreted as a sign of local flora, and a cue to spread of aliens. The relative use of alien $v s$ native species by honeybees could influence island pollination mutualisms and/or favour alien species. Analyzing pollen content data from honey samples an approach can be made to the relative foraging intensity on different plant communities and identify the importance of alien plant species in nearby areas.

Based on published information on pollen contents of honeys from beehives in La Palma, we made an indirect evaluation of the use of endemic, native and alien species by honeybees in two native forests of the island (evergreen laurel forest and Canarian pine forest).

Some of the most pervasive alien plants in the Canary Islands were represented in these pollen samples. The most frequent species in pollen counts was Castanea sativa. Proportion of alien species' pollen was significantly higher in the laurel forest, while the most visited group in the pine forest was that of endemics $(p<0.05)$. Specific composition of pollen samples analysed with Detrended Correspondence Analysis revealed (61.3\% variance explained) a pattern related to species distribution in each forest type.

Pollen content has revealed the presence of alien species in forests of La Palma, some of them considered invasive. The laurel forest is the most threatened of both ecosystems, mainly affected by the proximity to urban areas and the presence of intersperse arboreal plantations. The overall prevalence of aliens in the evaluated pollen data suggests that honeybees are prone to exploit exotics, and that the selection of plant species by honeybees in this oceanic island is not random. This may have serious consequences for island pollination systems and favour the spread of some exotic species.
\end{abstract}

\section{INTRODUCTION}

Conservation of native ecosystems on islands is threatened by several factors: habitat loss, degradation or fragmentation, introduction of alien species and predation by humans [1]. The presence of alien species in such ecosystems is the first step in the process of invasion [2-4] and these species are often used as indicators of the level of disturbance of natural areas and homogenization of biotas (i.e. $[5,6])$. In the Canary Islands, one of the most diverse regions in Europe, vascular plants are the most abundant taxonomic group of aliens, accounting for $46 \%$ of the total alien pool; from these, 79 plants species are considered invaders because they compete with native ones, transform their habitats or hybridize with them, favouring their own spreading over large areas [7]. La Palma, the second highest island of the Archipelago (2425 m a.s.1.), has been also the less studied regarding alien plant invasions in comparison with other high islands (i.e. [8-10]).

Address correspondence to this author at the Departmento de Ecología, Facultad de Biología, Universidad de La Laguna, Avda. Astrofísico Francisco Sánchez, s/n, La Laguna, 38206, Santa Cruz de Tenerife, Spain; E-mail: leadenas@ull.es
Apis mellifera L. (Hymenoptera, Apidae) is a generalist pollinator and when introduced on islands it is considered one of the most relevant invaders interfering with native ecosystems [11]. Introduced bees compete with native pollinators for floral resources, are vectors for pathogens to the native fauna, and pollinate both native and introduced plants modifying seed output, transferring pollen between species, disrupting the native pollination systems [12], and affecting the spread of alien plants [13]. A. mellifera in the Canary Islands is recorded as native [14]. Phylogenetic analyses indicate that the Canarian honeybees are a welldefined subset of the African evolutionary lineage of $A$. mellifera; nonetheless in some islands the introduction of foreign subspecies of honeybees by beekeepers (mainly from East European lineages) is causing a recent genetic introgression [15, 16]. Many authors still consider the honeybee as an alien species in the Canaries or at least in certain zones of the Archipelago, studying its effect on plantanimal networks [17-20]. A. mellifera in La Palma constitutes a genetically differentiated group from those of the remaining islands $[15,21]$. In fact, beekeepers from La Palma confirm that their colonies are formed by "black bee" which is the common name used for the Canarian honeybee, and that importation of foreign bees is a rare practise in the 
Island [22]. For these reasons, the possible role of populations of honeybees affecting the establishment and spread of alien plant species should be measured by its character of generalist pollinator but not considering bees as a recent introduction, at least in La Palma.

Many examples exist of bees visiting mainly introduced plants [13, 23-25].The generalist use of pollen sources by honeybees may provide useful information on the presence of alien species that may be, otherwise, detected at a higher cost or pass unnoticed. Honeybees often move relatively short distances on their areas of origin [26]. The exact foraging distance seems to depend on the abundance of profitable forage $[27,28]$, i.e. a foraging radius of only a few hundred meters was observed in agricultural areas. Given the distance over which bees can develop their food foraging (from $<1 \mathrm{~km}$ to $10 \mathrm{~km}$; [26, 29]), or water foraging activity [30], plants visited by honeybees might not be strictly limited to the vicinity of the beehives. Pollen spectrum is a reflection of the local flora, although the amount of pollen grains transferred to honey by bees depends inversely from the distance to the source of nectar [22].

Based on published information on pollen contents of honeys from beehives in La Palma [22], we aimed to make an indirect evaluation and explore possible consequences of the relative use of alien $v s$ native flowering plants by honeybees in two different forest types in La Palma. The hypotheses tested are: 1) honeybee makes a differential use of alien and native species when foraging in forested areas of La Palma, 2) the proportion of pollen content and therefore the relative presence of native $v s$ alien species will vary between both forest types and 3) the pool of species visited in each ecosystem would be different.

\section{MATERIALS AND METHODS}

\section{Study Site}

La Palma is located in the north-west of the Canary Islands. With a surface of $707 \mathrm{~km}^{2}$ is the fifth island in size being however the second highest one. Its size allows the existence of the main ecosystems present in the Islands, from small and fragmented stands of coastal shrubland in the western and north coast, to the summit scrub in the centre of the Cumbre Vieja massive and the border of La Caldera de Taburiente National Park. Two native forests are the most extended in the island: the evergreen laurel forest covers an almost continuous belt on the windward slope, varying in size depending on the level of disturbance; the pine forest occupies the largest area in the central part of the island and reaches low altitudes in the leeward slope (see Fig. 1). Both forests differ not only in their distribution but also in climate conditions and therefore in their floristic composition. The laurel forest ranges between 450 and $1500 \mathrm{~m}$ a.s.1., with a mean annual temperature of $13-18{ }^{\circ} \mathrm{C}$ and a mean annual rainfall of 500-1200 mm. Several tree species could be found in this forest with typical representation of elements of the Lauraceae, such as Laurus novocanariensis, Persea indica, Ocotea foetens, Apollonias barbujana, Ilex canariens, Picconia excelsa and Viburnum rigidum. The understory is mainly compound by ferns, some lianas and several shrubs. The laurel forest is bordered by the Erica-Myrica woody heath mainly in the transition to upper communities of pine forest, but also growing in areas where clear-cutting has been done for human uses. The pine forest ranges from 1500 to $2000 \mathrm{~m}$ a.s.1. in windward, and 900-2200 m.a.s.1. in leeward, although the pine forest in this island reaches lower altitudes when colonizing recent volcanic soils. Its mean annual temperature is $11-15^{\circ} \mathrm{C}$ and the mean amount of annual rainfall is $450-550 \mathrm{~mm}$. In contrast with laurel forest, the pine forest has only one arboreal species, the Canarian pine (Pinus canariensis) and its understory is poor in species, mainly leguminous shrubs (Chamaecytisus proliferus or Adenocarpus spp.) and leguminous herbs such as the endemic Lotus hillebrandii [31].

\section{Methods}

From the 20 beehives used in the study of La Serna et al. [22], data from only eight were chosen with the criterion of their location in forested areas. We selected four beehives in the pine forest and four beehives in the laurel forest (Fig. 1). Pollen data from 1992 to 1994 were qualitatively and quantitatively analyzed. Pollen extraction procedures are described in detail by La Serna et al. [22], who used an optical microscope to count and identify a minimum of 700 pollen grains in each sample. The process included obtaining pollen sediment by mixing the honey with sulphuric acid to dissolve sugars and colloids; after centrifuging, the sediment was processed with acetolysis eliminating polysaccharides and making grains more visible, which were finally preserved and mounted in glycerine jelly. The level of identification was species whenever possible; genus, family or pollen types were determined when species could not be assigned. Scientific names of plant species detected from pollen were reviewed following the check list of wild species of the Canary Islands [32]. According to this list the status of each taxon was assigned differentiating three categories: native, endemic or alien. Taxa identified only to the family or genus level were assigned to the most common status for the species belonging to the taxa present in La Palma. The percentage of pollen content by taxa was taken from the data recorded in La Serna's honey files [22] corresponding to the selected beehives.

When interpreting our results, some aspects of pollen dispersal by honeybees should be taken into account. There are some species that might be overrepresented in the honey; these are mainly species that produced high quantities of pollen of low size (i.e. Castanea sativa, Eucalyptus sp., L. hillebrandii); other species could be underrepresented because they produce less pollen (i.e. Lavandula canariensis) or because their pollen grains are too fragile and do not resist the acetolysis process, such as Lauraceae species. Other factors affect the contribution of pollen in honeys: distance to the source plant, shape of flowers, pollination type, size of pollen grains or methods used for the extraction of honey from honeycombs, are some of them [33].

\section{Statistical Analysis}

Mean pollen percentage of each taxon from the three years of sampling was calculated for each beehive. Mean values were grouped in endemic, native and alien categories and tested for normality with Kolmogorov-Smirnov test, 


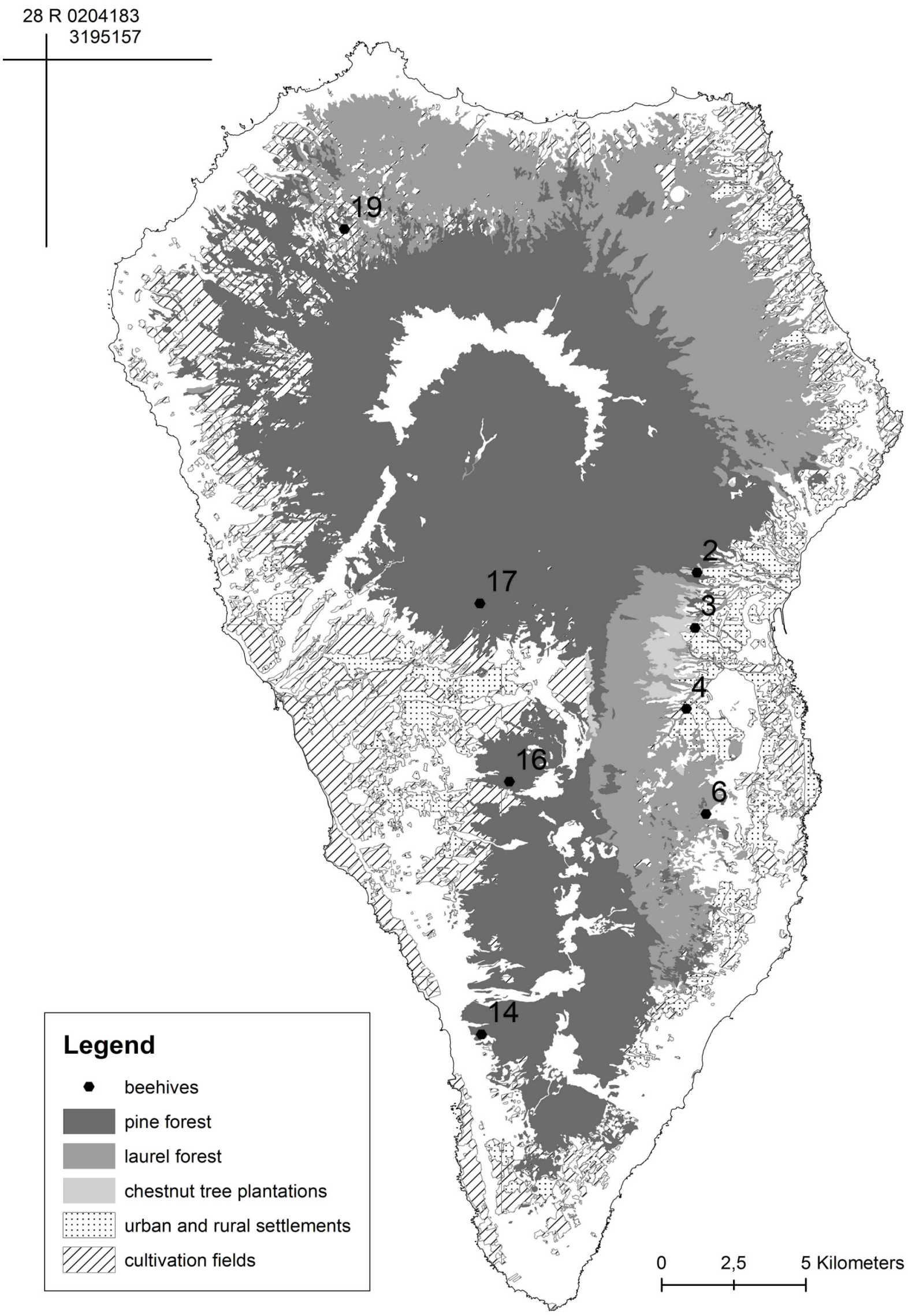

Fig. (1). Location of beehives and distribution in the two main forest types of La Palma (laurel and pine forest). Anthropogenic areas (chestnut tree plantations, urban areas and rural settlements, cultivation fields) are drawn. 
showing a non-normal distribution $(p<0.05)$. Mean percentages of each status were compared between both forests types by nonparametric Mann-Whitney $U$ test, verified with the Monte Carlo method with 10000 iterations for $p<0.05$. Within each ecosystem (laurel forest and pine forest) differences among the three statuses were analysed using Kruskal-Wallis test, estimating $p$-values using Monte Carlo sample iteration $(10000$ iterations for $p<0.05)$. Monte Carlo bilateral significance was used to avoid erroneous significance values in nonparametric tests due to the low number of samples analysed $(n=8)$. When differences were detected a pair wise comparison was done using the nonparametric Tukey test to find out which categories showed significant differences in each forest type. As $C$. sativa percentage accounts for more than $50 \%$ in the total pollen content (see results), all tests were repeated excluding pollen of $C$. sativa from the total sum and recalculating percentages for the remaining taxa.

Ordination techniques were used to explain the variation in species composition of beehives. We applied a Detrended Correspondence Analysis (DCA) [34] with the beehives as samples $(\mathrm{n}=8)$ and the pollen proportions of all the species found $(\mathrm{n}=59)$. Coefficients of Spearman rank-correlations were calculated between the sample coordinates from the DCA and spatial variables: altitude of beehive location and distances to anthropogenic areas (urban areas and rural settlements, cultivation fields and plantations of chestnut trees), which could be affecting the presence of alien species in the samples. Distances were calculated with the proximity toolset of ArcGIS 9.0 [35] based on the vegetation map and the topographic map (1:5000) of La Palma [36]. Nonparametric tests were performed with SPSS 15.0 [37], except for Tukey test calculated following Zar [38], ordination analysis was done using the CANOCO package [39].

\section{RESULTS}

More than $50 \%$ of the pollen obtained from honey samples belonged to chestnut (Fig. 2). C. sativa is clearly overrepresented in the data set because it is not only anemophilous but also an entomophilous species, and produces high amounts of pollen. From the 59 species used for foraging by honeybees (see Appendix), four species were the most visited. C. sativa is the only introduced one, Reseda luteola is native and the other two are endemic species from La Palma L. hillebrandii and Carlina falcata. If we attend to the species contributing with less than $5 \%$ and more than 0.5 $\%$ of pollen we could find a set mainly compound by native species (Fig. 2). Finally, there is a group with a lower contribution of pollen $(<0.5 \%)$ formed by 20 natives, 17 aliens, and 6 endemics (see also Appendix).

Grouping species by their status as endemics, natives and aliens we could detect some differences in their pollen content depending on the forest type (Table 1). When we considered pollen of $C$. sativa in the total contribution, there were significant differences in the pollen contribution of endemic and alien species, endemics being more abundant in the pine forest and aliens more represented in the laurel forest. However, when excluding the C. sativa pollen from the total sum, significant differences arises in the proportion of pollen from endemic and native species. Endemics again have a higher contribution in the pine forest whereas natives are higher in the laurel forest.

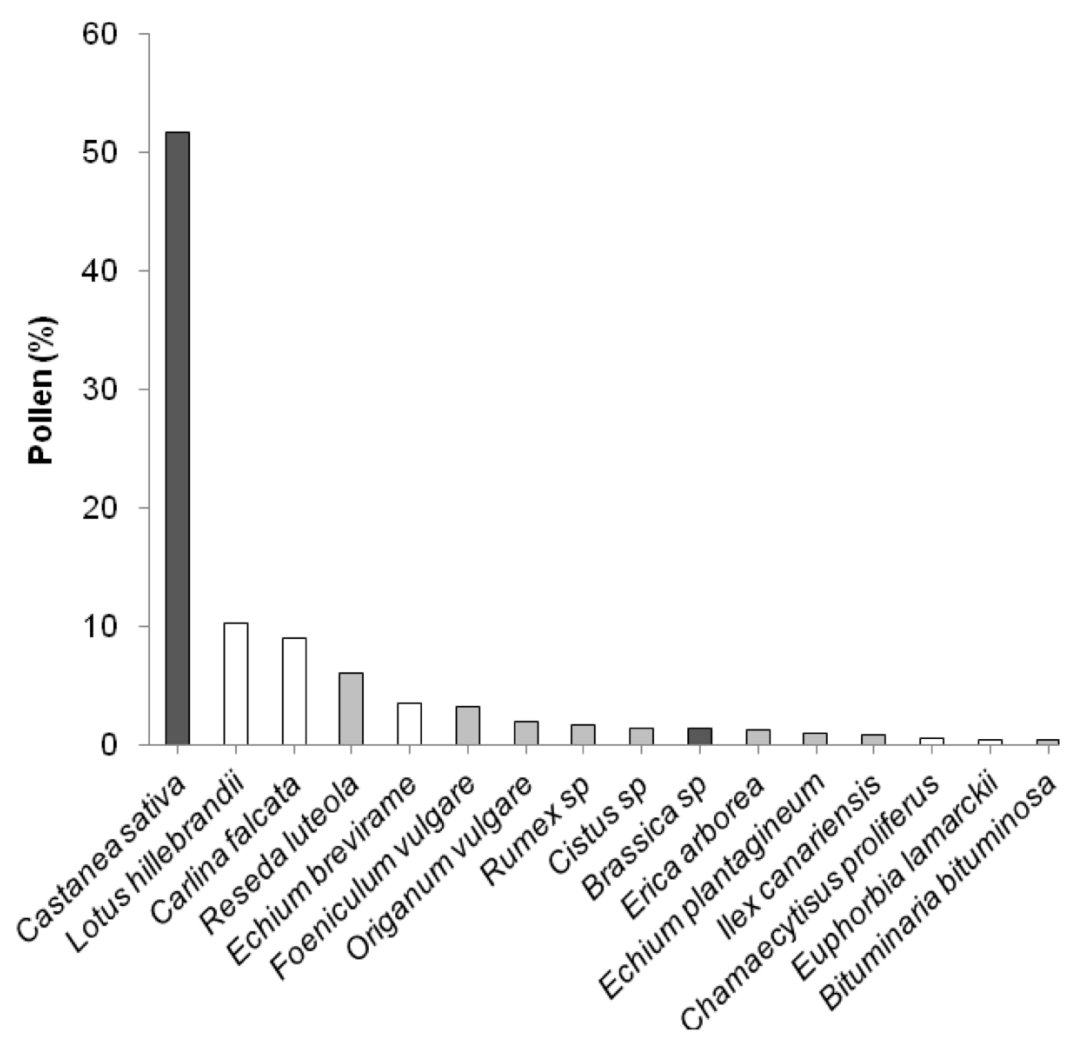

Fig. (2). Total percentage of pollen of species present in honey samples of La Palma. Only species with more than $0.5 \%$ of pollen are shown. Alien species coloured in dark grey, native species in light grey and endemic species in white. 
Table 1. Percentage of Pollen for Endemic, Native and Alien Species in the Laurel and Pine Forests of La Palma. Significant Differences Between the Two Forests were Examined Using Mann-Whitney $U$ Test

\begin{tabular}{|c|c|c|c|c|}
\hline \multirow{2}{*}{ Percentage of Pollen } & \multicolumn{2}{|c|}{ Forest Type } & \multirow{2}{*}{$\boldsymbol{U}$} & \multirow{2}{*}{$p$ Values } \\
\hline & Laurel Forest & Pine Forest & & \\
\hline \multicolumn{5}{|l|}{ Including $C$. sativa pollen } \\
\hline Endemic species (E) & $1.63 \pm 1.96$ & $44.90 \pm 32.24$ & 18.50 & 0.004 \\
\hline Native species $(\mathrm{N})$ & $30.55 \pm 27.06$ & $16.45 \pm 13.25$ & 47.00 & 0.471 \\
\hline Alien species (A) & $68.68 \pm 27.99$ & $40.82 \pm 30.62$ & 24.00 & 0.035 \\
\hline \multicolumn{5}{|l|}{ Excluding $C$. sativa pollen } \\
\hline Endemic species (E) & $8.16 \pm 6.10$ & $58.75 \pm 33.82$ & 16.00 & 0.003 \\
\hline Native species $(\mathrm{N})$ & $85.81 \pm 9.96$ & $38.00 \pm 31.02$ & 17.00 & 0.004 \\
\hline Alien species (A) & $6.03 \pm 5.41$ & $3.52 \pm 3.18$ & 41.00 & 0.390 \\
\hline
\end{tabular}

Values are means ( \pm Standard Deviation), significant differences are shown in bold (significance of Monte Carlo bilateral method for $p<0.05$ ).

Significant differences appeared as well when comparing the contribution of each status within each forest type (Fig. 3). When considering $C$. sativa pollen in the total sum, significant differences were found only in the laurel forest $\left(\chi^{2}=19.83, \mathrm{df}=2, p<0.05\right)$, where the contribution of alien and native pollen was similar but significantly higher than endemic pollen $(p<0.05)$. In the second case, excluding pollen from $C$. sativa, we obtained significant differences within both forest types (laurel forest, $\chi^{2}=17.61, \mathrm{df}=2, p<$ 0.05 ; pine forest, $\left.\chi^{2}=19.71, \mathrm{df}=2, p<0.05\right)$. The proportion of native pollen in the laurel forest was significantly higher $(p<0.05)$ than the two other groups (endemic and alien) that did not show significant differences between them. In the pine forest endemics and natives had the higher proportions and both groups differed significantly compared with the low proportion of alien pollen $(p<0.05)$.
Ordination analysis explained a cumulative percentage of variance of $61.3 \%$ with the first two axes (Fig. 4). The first axis revealed a pattern of species composition related to the location of beehives (samples) in different forest types. Beehives located in the pine forest had higher values in the first axis (except for beehive number 2) (Fig. 5). Representative species from the pine forest had also high values in the first axes such us $L$. hillebrandii, $P$. canariensis, Cistus sp. or C. proliferus. Other species with high values in this axis are more common in the coastal shrubland (Euphorbia lamarckii, Kleinia neriifolia, Echium brevirame, Rumex $s p$. or L. canariensis) which might be indicating its proximity to the border of the pine forest, especially in the leeward slope where this community forms a belt of substitution of the potential thermophilous communities. Also, with high values in axis I, were ruderal a)

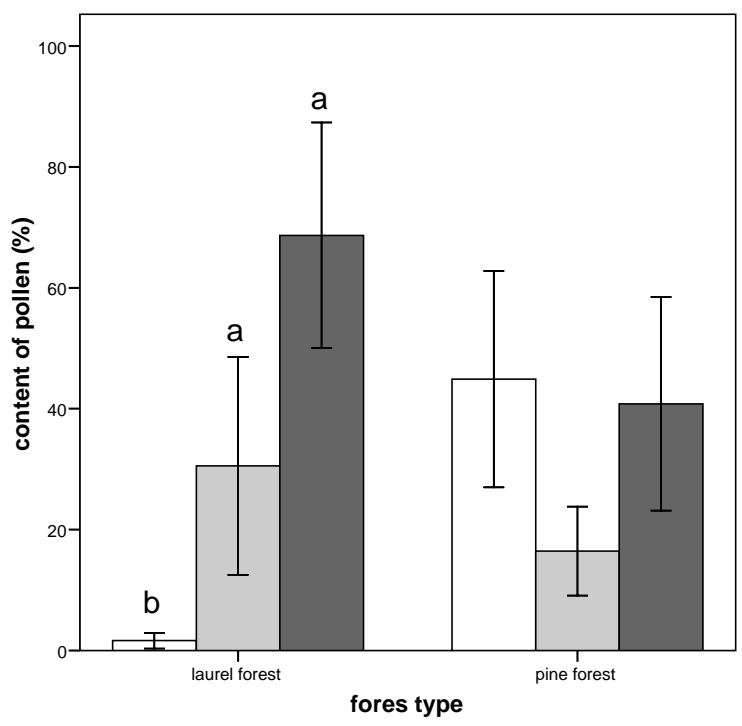

b)

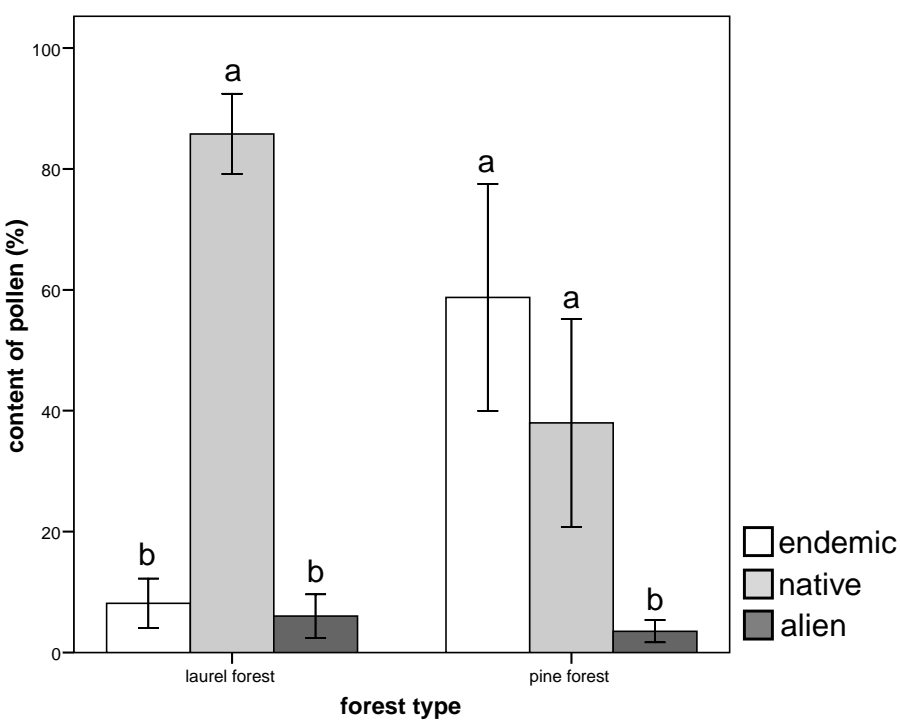

Fig. (3). Comparison of endemic (E), native (N) and alien (A) species within each forest type, a) including pollen from $C$. sativa and; b) excluding pollen from $C$. sativa. Differences among status were tested with Kruskal-Wallis test $(p<0.05)$ and the post hoc non parametric Tukey test (significant differences are shown with letters $p<0.05$ ). Error bars show $95 \%$ confidence interval. 
species such as Malva sp., Silene sp., Echium plantagineum, Dittrichia viscosa or Asphodelus ramosus. There were few alien species with higher values in this axis Acacia sp., Cardiospermum grandifolium and Schinus molle (Fig. 4). Beehives located in the laurel forest had lower values in axis I (Figs. 4, 5). Some characteristic species from this forest type showed also low values in this axis, such as Erica arborea, Myrica faya or V. rigidum, as well as species from the relicts of thermophilous woodland like Phoenix canariensis, Jasminum odoratisimum or Convolvulus sp. However, most of the species are ruderal (Tuberaria guttata, Achyranthes aspera, Foeniculum vulgare, Bidens pilosa, etc.) or alien (Tropaeolum majus, Eucalyptus sp., Ligustrum sp., Opuntia maxima, Ageratina adenophora or C. sativa, the most abundant in these beehives).
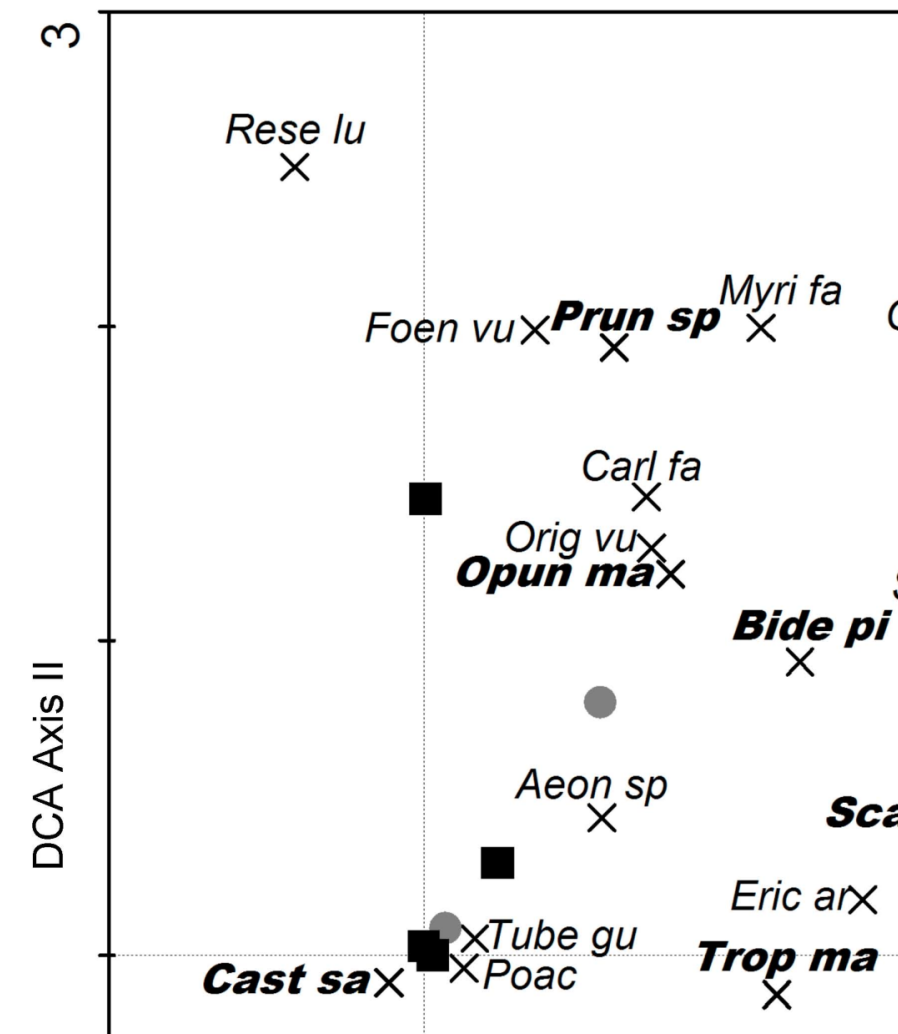

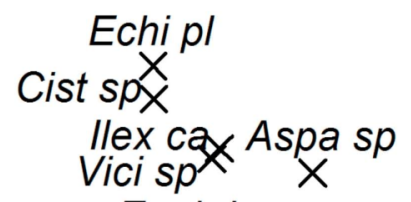

Euph lax Rume spX

Echi br Acac sp Lotu hi

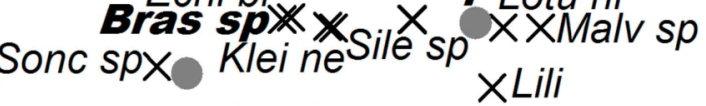

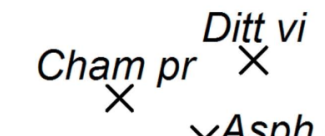<smiles>C1CCCCC1</smiles>

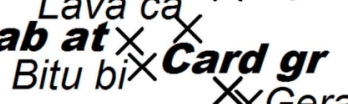

$X$ Schi mo

$X$ Gala to

$\times$ Pinu ca

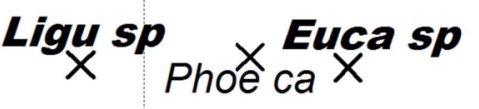

Convsp $\times$ Achy as Datu in

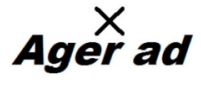

\section{Chen Amar}

Plan spX.pass ed

Bryo ve Sech ed

Alli $s p$ Zea ma

Y

Ephe fr. Yucc el

Vibu ri Jasm od

DCA Axis I

\section{SAMPLES}

Laurel forest

Pine forest

SPECIES

$X$

Fig. (4). Biplot of DCA with species and samples (beehives). Eigenvalues for axis $\mathrm{I}=0.807$ and axis II $=0.415$ (cumulative percentage of variance for species composition is $61.3 \%$ ). The total inertia of the analysis was 1.993 . Species are labelled with the first four letters of the family/genus and the first two letters of the specific epithet (see Appendix). Alien species are shown in bold. 


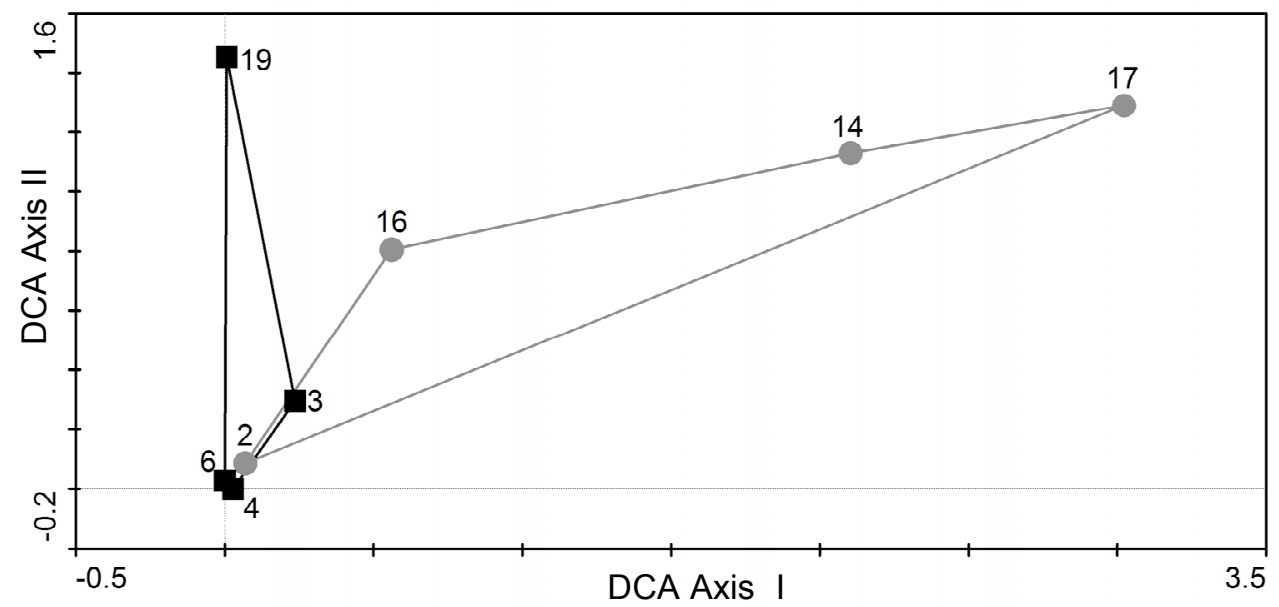

Fig. (5). Scatter plot of DCA with samples (beehives). Envelopes enclose two groups, beehives located in pine forest (grey circles) and beehives located in laurel forest (black squares).

Whilst the first axis was not correlated with any of the spatial variables, the second axis showed a significant and positive correlation with distances to urban areas and rural settlements and to chestnut tree plantations (Table 2). The second axis evidenced the level of disturbance of the flora around the beehives. Higher values of the second axis show locations that are at farther distances from human settlements and from chestnut tree plantations. In fact most of the alien species had negative values in the second axis (Fig. 4). Species composition around the beehives in the pine forest indicates less disturbed vegetation whereas composition in the laurel forest samples would be more influenced by human activities. Two exceptions could be observed in the scatter plot with beehives (Fig. 5). Beehive number two is mixed with the laurel forest group because, although located in the pine forest, it is very close to chestnut tree plantations and the contribution from $C$. sativa pollen is very high (around $80 \%$ ), but also because it is near to urban areas and stands of the laurel forest and it appears to have an important contribution of ruderal species and species more typical of the laurel forest. Beehive number 19, located in the laurel forest, is separated from this group in the second axis, probably because it is very far from C. sativa plantations and had a lower contribution of this species (around 30\%) and it is also the most distant from disturbed areas determining a low contribution of ruderal species, besides this beehive had a high content of pollen from $R$. luteola (around 50\%).

\section{DISCUSSION}

The alien species, C. sativa, was the most frequently or intensely foraged by honeybees, although when excluding this overrepresented species from the samples the frequency of native plus endemic species visited was higher than that of alien species. Alien species visited by honeybees in the forested ecosystems of La Palma are mainly planted trees such as chestnut and almond trees or eucalyptus (C. sativa, Prunus dulcis, Eucalyptus spp.) or the prickly pear (O. maxima), all cultivated in the last centuries for their feed or wood values [40, 41]. Other less represented might be introduced as ornamental plants as Acacia cyanophylla, Ligustrum sp., T. majus or S. molle. Two alien species detected by their pollen, Passiflora edulis and Yucca elephantipes, are not quoted in the Canarian check list [32] and we assume that their distribution might be still limited to gardens. Eucalyptus spp., S. molle, Ligustrum spp. and Sechium edulis are not quoted for La Palma but appear in other islands of the Archipelago as introduced [32]. Some of the alien species detected are considered as invaders because of: 1) having an evident invasive behaviour in the Canary Islands, this is the case of $A$. adenophora, T. majus, $C$. grandiflorum, Eucalyptus sp. and O. maxima, 2) showing invasive behaviour that is incipient or restricted to low-value ecosystems as A. cyanophylla or S. molle, 3) presenting invasive behaviour in another temperate and tropical insular regions as Ligustrum sp. and Passiflora sp. [42]. Attending to ecosystems, A. adenophora, A. cyanophylla and T. majus have been since long considered invasive alien species of natural and potential areas of laurel forest [43].

Honeybees in the laurel forest forage mainly on alien and native species, whereas in the pine forest the presence of alien pollen is significantly lower. This result is influenced by the presence of chestnut tree plantations in the area where beehives were located and because of the high production of pollen by $C$. sativa. But if we ignore the contribution of this overrepresented species, the most visited group in the laurel forest would be that of natives. In the pine forest, however honeybees always prefer endemic species for foraging. On the contrary alien species would be the less frequently visited in both forest types. This apparent election of different groups of species might have different consequences for each forest. Alien species can affect the pollination success in natives, either through reduced pollinator visitation rates or through increased heterospecific pollination of native flowers [44]. Chestnut trees might be sharing pollinators with other insect-pollinated species in the laurel forest, such as Lauraceae. This competition affects pollination and reproductive success of natives, in this case reducing their seed production [45]. However, the effect of alien species could be the opposite; increased floral resources provided by aliens may have facilitative effects on natives, through increased pollinator densities resulting in increased visitation rates and seed production to native plant species [44]. Honeybees could be also favouring pollination and seed set of chestnut trees in the laurel forest, as shown 
Table 2. Elevation and Distances from Beehives to Anthropic Areas Measured in Meters. Spearman Correlation Coefficients Between Each Spatial Variable and DCA Axes were Calculated $\left({ }^{*} p<0.05\right)$

\begin{tabular}{|c|c|c|c|c|}
\hline Beehives & Elevation (m) & $\begin{array}{l}\text { Distance to Urban Areas and } \\
\text { Rural Settlements (m) }\end{array}$ & Distance to Fields (m) & $\begin{array}{c}\text { Distance to Chestnut Trees } \\
\text { Plantations (m) }\end{array}$ \\
\hline \multicolumn{5}{|c|}{ Laurel forest } \\
\hline 4 & 520 & 40.5 & 11.6 & 556.6 \\
\hline 6 & 800 & 592.2 & 252.0 & 90.9 \\
\hline \multicolumn{5}{|c|}{ Pine forest } \\
\hline 2 & 580 & 38.4 & 1005.9 & 7.0 \\
\hline 14 & 700 & 3542.0 & 414.7 & 6287.4 \\
\hline 16 & 1040 & 1318.7 & 279.8 & 3288.9 \\
\hline Axis I & 0.286 & 0.167 & 0.548 & 0.357 \\
\hline Axis II & 0.619 & $0.762 *$ & -0.048 & $0.714 *$ \\
\hline
\end{tabular}

by many cases of introduced or native pollinators which favour pollination of alien species (see examples in [2]). In the pine forest, pollination of endemic species by honeybee could have a direct effect on seed production (as explained above) or modifying pollen flow and favouring inbreeding when bees visit flowers of the same plant repeatedly [45].

Floristic differences were detected between both forest types based on the pollen content of honey samples. Species composition in the region around beehives located in both forests share little species in common. The pine forest was the less invaded by both alien and ruderal species. A previous study on the distribution of alien species on two altitudinal gradients in Tenerife (0-2300 m a.s.l.) and Gran Canaria (0-1950 $\mathrm{m}$ a.s.l.) shows how alien plants presented a unimodal distribution pattern along the altitudinal gradient, with less species and lower abundance at low and high altitudes, and higher abundance at intermediate altitudes [8]. However, we did not find any correlation between the altitude and the species composition around beehives, probably because our study sites do not embrace the whole altitudinal gradient of the pine forest in La Palma [31] and altitudinal ranges analyzed in this study coincide in both ecosystems (500-1160 m a.s.1.). Altitudinal correlation with alien species richness was not found either in an altitudinal gradient (0-650 $\mathrm{m}$ a.s.1.) studied in Tenerife [10], suggesting that altitudinal ranges need to be larger in order to show correlation with alien species richness. Another reason explaining the absence of many alien species could be the thick layer of litter commonly accumulated in the Canarian pine forest which prevents from colonization of both alien and native species [8]. Floristic composition, however, is significantly related with distance to urban areas and rural settlements and distance to chestnut tree plantations. This gradient could be observed from sites which are less invaded by alien and ruderal species mostly coinciding with beehives in the pine forest, to more disturbed sites, where alien and ruderal species are best represented, in the laurel forest. This inverse correlation between alien species richness and distance to urban areas was also found in Tenerife and Gran Canaria $[8,10]$, explained by the increase of "propagule pressure" near to anthropogenic areas [46]. The proximity of chestnut tree plantations to laurel forest sites is well detected in honey samples; other alien species with a lower contribution are mainly detected in this forest indicating that this community is richer in alien species. Laurel forests in La Palma have been subject to exploitation (at least during the last 500 years) for timber and fodder [47]. These traditional activities have been maintained until present, making this forest the most exposed to alien plant invasions in La Palma. The effects of these invasions in the laurel forest should be studied so that control and other management efforts could be done efficiently and when necessary [48]. But special attention might be paid also to the less known alien invasive species that were detected in this study.

\section{APPENDIX}

Species names and abbreviations used in the DCA biplot. Status $(\mathrm{A}=$ alien, $\mathrm{E}=$ endemic, $\mathrm{N}=$ native $)$ and scientific names follows Acebes et al. [32]. Pollen content indicates the mean percentage of each species in all samples analysed.

\begin{tabular}{|l|c|c|c|}
\hline \multicolumn{1}{|c|}{ Species Name } & Abbreviation & Status & $\begin{array}{c}\text { Pollen } \\
\text { Content (\%) }\end{array}$ \\
\hline \hline Acacia $s p$ & Acac sp & $\mathrm{A}$ & 0.02 \\
Achyranthes aspera & Achy as & $\mathrm{A}$ & 0.17 \\
Aeonium sp & Aeon $s p$ & $\mathrm{~N}$ & 0.30 \\
Ageratina adenophora & Ager ad & $\mathrm{A}$ & 0.03 \\
Allium sp & Alli $\mathrm{sp}$ & $\mathrm{N}$ & 0.04 \\
Asparagus sp & Aspa $\mathrm{sp}$ & $\mathrm{N}$ & 0.13 \\
Asphodelus ramosus & Asph $r a$ & $\mathrm{~N}$ & 0.27 \\
\hline
\end{tabular}


(Appendix) contd.....

\begin{tabular}{|c|c|c|c|}
\hline Species Name & Abbreviation & Status & $\begin{array}{c}\text { Pollen } \\
\text { Content (\%) }\end{array}$ \\
\hline Bidens pilosa & 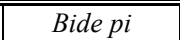 & $\overline{\mathrm{A}}$ & 0.36 \\
\hline Bituminaria bituminosa & Bitu bi & $\mathrm{N}$ & 0.50 \\
\hline Brassica sp & Bras $s p$ & A & 1.40 \\
\hline Bryonia verrucosa & Bryo ve & $\mathrm{E}$ & 0.02 \\
\hline Cardiospermum grandiflorum & Card gr & A & 0.08 \\
\hline Carlina falcata & Carlfa & $\mathrm{E}$ & 9.00 \\
\hline Castanea sativa & Cast sa & A & 51.64 \\
\hline Chamaecytisus proliferus & Cham pr & $\mathrm{E}$ & 0.67 \\
\hline Chenopodiaceae-Amaranthaceae & Chen Amar & $\mathrm{N}$ & 0.14 \\
\hline Cistus sp & Cist $s p$ & $\mathrm{~N}$ & 1.44 \\
\hline Convolvulus sp & Conv $s p$ & $\mathrm{~N}$ & 0.01 \\
\hline Datura innoxia & Datu in & A & 0.01 \\
\hline Dittrichia viscosa & Ditt vi & $\mathrm{N}$ & 0.09 \\
\hline Echium brevirame & Echi br & $\mathrm{E}$ & 3.51 \\
\hline Echium plantagineum & Echipl & $\mathrm{N}$ & 1.00 \\
\hline Ephedra fragilis & Ephe fr & $\mathrm{N}$ & 0.00 \\
\hline Erica arborea & Eric ar & $\mathrm{N}$ & 1.34 \\
\hline Eucalyptus sp & Euca sp & A & 0.28 \\
\hline Euphorbia lamarckii & Euph la & $\mathrm{E}$ & 0.51 \\
\hline Foeniculum vulgare & Foen $v u$ & $\mathrm{~N}$ & 3.21 \\
\hline Galactites tomentosa & Gala to & $\mathrm{N}$ & 0.20 \\
\hline Geranium sp & Gera sp & $\mathrm{N}$ & 0.02 \\
\hline Ilex canariensis & Ilex ca & $\mathrm{N}$ & 0.84 \\
\hline Jasminum odoratissimum & Jasm od & $\mathrm{N}$ & 0.00 \\
\hline Kleinia neriifolia & Klei ne & E & 0.03 \\
\hline Lavandula canariensis & Lava ca & $\mathrm{E}$ & 0.31 \\
\hline Ligustrum $s p$ & Ligu $s p$ & A & 0.02 \\
\hline Liliaceae & Lili & $\mathrm{N}$ & 0.02 \\
\hline Lotus hillebrandii & Lotu hi & E & 10.34 \\
\hline Malva sp & Malv sp & $\mathrm{N}$ & 0.00 \\
\hline Myrica faya & Myrifa & $\mathrm{N}$ & 0.32 \\
\hline Opuntia maxima & Opun ma & A & 0.21 \\
\hline Origanum vulgare & Orig vu & $\mathrm{N}$ & 1.97 \\
\hline Passiflora edulis & Pass ed & A & 0.02 \\
\hline Phoenix canariensis & Phoe ca & $\mathrm{E}$ & 0.26 \\
\hline Pinus canariensis & Ріпи са & $\mathrm{E}$ & 0.01 \\
\hline Plantago $s p$ & Plan $s p$ & $\mathrm{~N}$ & 0.01 \\
\hline Poaceae & Poac & $\mathrm{N}$ & 0.12 \\
\hline Prunus sp & Prun $s p$ & A & 0.36 \\
\hline Reseda luteola & Rese lu & $\mathrm{N}$ & 6.04 \\
\hline Rumex sp & Rume sp & $\mathrm{N}$ & 1.77 \\
\hline Scabiosa atropurpurea & Scab at & A & 0.06 \\
\hline Schinus molle & Schi mo & A & 0.02 \\
\hline Sechium edule & Seched & A & 0.01 \\
\hline Silene $s p$ & Sile $s p$ & $\mathrm{~N}$ & 0.12 \\
\hline Sonchus sp & Sonc $s p$ & $\mathrm{~N}$ & 0.36 \\
\hline Tropaeolum majus & Trop ma & A & 0.09 \\
\hline Tuberaria guttata & Tube gu & $\mathrm{N}$ & 0.10 \\
\hline Viburnum rigidum & Vibu ri & $\mathrm{E}$ & 0.02 \\
\hline Vicia $s p$ & Vicisp & $\mathrm{N}$ & 0.11 \\
\hline Yucca elephantipes & Yucc el & A & 0.00 \\
\hline Zea mays & Zea ma & A & 0.02 \\
\hline
\end{tabular}

\section{REFERENCES}

[1] Whitaker RJ, Fernández-Palacios JM. Island Biogeography. Ecology, Evolution and Conservation. $2^{\text {nd }}$ ed. Oxford: Oxford University Press 2007.

[2] Richardson DM, Allsopp N, D’Antonio CM, Milton SJ, Rejmánek M. Plant invasions-the role of mutualisms. Biol Rev (Camb) 2000; 75: 65-93.
[3] Prinzing A, Durka W, Klotz S, Brandl R. Which species become aliens? Evol Ecol Res 2002; 4: 385-405.

[4] Reaser JK, Meyerson LA, Cronk Q, et al. Ecological and socioeconomic impacts of invasive alien species in island ecosystems. Environ Conserv 2007; 34: 1-14.

[5] Stapanian MA, Sundberg SD, Baumgardner GA, Liston A. Alien plant species composition and associations with anthropogenic disturbance in North American forests. Plant Ecol 1998; 139: 4962 .

[6] Honnay O, Endels P, Vereecken H, Hermy M. The role of patch area and habitat diversity in explaining native plant species richness in disturbed suburban forest patches in northern Belgium. Divers Distrib 1999; 5: 129-41.

[7] Martín JL, Marrero MC, Zurita N, Arechavaleta M, Izquierdo I. Biodiversidad en gráficas. Especies silvestres de las Islas Canarias. Santa Cruz de Tenerife: Consejería de Medio Ambiente y Ordenación Territorial, Gobierno de Canarias 2005.

[8] Arévalo JR, Delgado GJD, Otto R, Naranjo A, Salas M, FernándezPalacios JM. Exotic species in the roadside plant communities through an altitudinal gradient in Tenerife and Gran Canaria (Canary Islands). Perspect Plant Ecol Evol Syst 2005; 7: 185-202.

[9] Arévalo JR, Afonso L, Naranjo A, Salas M. Invasion of the Gran Canaria ravines ecosystems (Canary Islands) by the exotic species Acacia farnesiana. Plant Ecol 2009; DOI 10.1007/s11258-0099633-0.

[10] Arteaga M, Delgado JD, Rüdiger O, Fernández-Palacios JM, Arévalo JR. How do alien plants distribute along roads on oceanic islands? A case study in Tenerife, Canary Islands. Biol Invasions 2009; 11: 1071-86.

[11] Hansen DM, Olesen JM, Jones CG. Trees, birds and bees in Mauritius: exploitative competition between introduced honey bees and endemic nectarivorous birds? J Biogeogr 2002; 29: 721-34.

[12] Paini DR, Roberts JD. Commercial honey bees (Apis mellifera) reduce the fecundity of an Australian native bee (Hylaeus alcyoneus). Biol Conserv 2005; 123: 103-12.

[13] Goulson D. Effect of Introduced Bees on Native Ecosystems. Annu Rev Ecol Evol Syst 2003; 34: 1-26.

[14] Baéz M, Koponen M, García A, Martín E. In: Izquierdo I, Martín JL, Zurita N, Arechavaleta M, Eds. Hymenoptera. Lista de especies silvestres de Canarias (hongos plantas y animales terrestres). Santa Cruz de Tenerife: Consejería de Medio Ambiente y Ordenación Territorial, Gobierno de Canarias 2004; 281-300.

[15] De la Rúa P, Galián J, Serrano J, Moritz RFA. Genetic structure and distinctness of Apis mellifera L. populations from the Canary Islands. Mol Ecol 2001; 10: 1733-42.

[16] De La Rúa P, Serrano J, Galián J. Biodiversity of Apis mellifera populations from Tenerife (Canary Islands) and hybridization with East European races. Biodivers Conserv 2002; 11: 59-67.

[17] Valido A, Dupont YL, Hansen DM. Native birds and insects, and introduced honey bees visiting Echium wildpretii (Boraginaceae) in the Canary Islands. Acta Oecol 2002; 23: 413-9.

[18] Dupont YL, Hansen DM, Olesen JM. Structure of a plant-flowervisitor network in the high-altitude sub-alpine desert of Tenerife, Canary Islands. Ecography 2003; 26: 301-10.

[19] Dupont YL, Hansen DM, Valido A, Olesen JM. Impact of introduced honey bees on native pollination interactions of the endemic Echium wildpretii (Boraginaceae) on Tenerife, Canary Islands. Biol Conserv 2004; 118: 301-11.

[20] Padrón B, Traveset A, Biedenweg T, Díaz D, Nogales M, Olesen MJ. Impact of Alien Plant Invaders on Pollination Networks in Two Archipelagos. PLoS One 2009; 4: e6275.

[21] Granda I. Rastreando los genes de la abeja negra. Canarias Agraria y Pesquera 2003; 69: 12-4.

[22] La Serna IE, Méndez B, Gómez C. Aplicación de nuevas tecnologías en mieles canarias para su tipificación y control de calidad. Santa Cruz de Tenerife: Servicio de Publicaciones de la Caja General de Ahorros de Canarias 1997.

[23] Stimec J, Scott-Dupree CD, McAndrews JH. Honey bee, Apis mellifera, pollen foraging in southern Ontario. Can Field-Nat 1997; 111: 454-6.

[24] Hanley ME, Goulson D. Introduced weeds pollinated by introduced bees: Cause or effect? Weed Biol Manage 2003; 3: 204-12.

[25] Lopezaraiza-Mikel MA, Hayes RB, Whalley MR, Memmott J. The impact of an alien plant on a native plant-pollinator network: an experimental approach. Ecol Lett 2007; 10: 539-50. 
[26] Roubik DW. Ecology and Natural History of Tropical Bees. New York: Cambridge University Press 1989.

[27] Visscher PK, Seeley TD. Foraging strategy of honeybee colonies in a temperate deciduous forest. Ecology 1982; 63: 1790-801.

[28] Beekman M, Ratnieks FLW. Long-range foraging by the honeybee, Apis mellifera L. Funct Ecol 2000; 14: 490-6.

[29] Winston ML. The biology of honey bees. Cambridge, MA: Harvard University Press 1987.

[30] Visscher PK, Crailsheim K, Sherman G. How do honey bees (Apis mellifera) fuel their water foraging flights? J Insect Physiol 1996; 42: 1089-94.

[31] del Arco MJ, Wildpret W, Pérez PL, et al. Mapa de vegetación de Canarias. Santa Cruz de Tenerife: GRAFCAN 2006.

[32] Acebes JR, del Arco M, García A, et al. In: Izquierdo I, Martín JL, Zurita N, Arechavaleta M, Eds. Pteridophyta, Spermatophyta. Lista de especies silvestres de Canarias (hongos plantas y animales terrestres). Santa Cruz de Tenerife: Consejería de Medio Ambiente y Ordenación Territorial, Gobierno de Canarias 2004; 96-43.

[33] Maurizio A. In: Crane E, Ed. Honey: a comprehensive survey. London: Heinemann 1975; 77-105.

[34] Gauch HG. Multivariate analysis in community ecology. Cambridge: Cambridge University Press 1982.

[35] ESRI. Introducción a ArcGIS para ArcView, ArcEditor y ArcInfo. ESRI 2000.

[36] GRAFCAN [homepage on the internet]. Mapa Topográfico a escala 1:5.000 de Canarias (2007/2008). Mapa de Vegetación, La Palma (2002/2003). Available from: http://www.idecan.grafcan.es (Date of Access: September 11, 2009).

[37] Visauta B. Análisis estadístico con SPSS 14. Estadística básica. 3rd ed. Madrid: Mc Graw Hill; 2007.

[38] Zar JH. Biostatistical analysis. $2^{\text {nd }}$ ed. New Jersey: Prentice-Hall International Editions 1984
[39] Ter Braak CJF, Šmilauer P. CANOCO Reference manual and user's guide to Canoco for Windows, software for canonical community ordination (version 4). Ithaca: Microcomputer Power; 1998.

[40] Marrero A, Capote J. La agricultura. In: Fernández-Palacios JM, Martín JL, Eds. Naturaleza de las Islas Canarias. Ecología y conservación. 2nd ed. Santa Cruz de Tenerife: Publicaciones Turquesa 2002; 263-8.

[41] Naranjo J. Los aprovechamientos forestales. In: Fernández-Palacios JM, Martín JL, Eds. Naturaleza de las Islas Canarias. Ecología y conservación. 2nd ed. Santa Cruz de Tenerife: Publicaciones Turquesa 2002; pp. 269-74.

[42] Sanz-Elorza M, Dana ED, Sobrino E. Aproximación al listado de plantas vasculares alóctonas invasoras reales y potenciales en las Islas Canarias. Lazaroa 2005; 26: 55-66.

[43] García A, Wildpret W, Martín V. Especies vegetales consideradas invasoras de hábitats, en la Historia Natural de Canarias. Lazaroa 2008; 29: 49-67.

[44] Bjerknes AL, Totland O, Hegland SJ, Nielsen A. Do alien plant invasions really affect pollination success in native plant species? Biol Conserv 2007; 138: 1-12.

[45] Traveset A, Santamaría L. Consecuencias de la introducción de especies exóticas en la disrupción de los mutualismos en islas. In: Fernández-Palacios JM, Morici C, Eds. Island Ecology. La Palma: Asociación Española de Ecología Terrestre, Cabildo de La Palma 2004; pp. 251-76.

[46] Rouget M, Richardson DM. Inferring process from pattern in plant invasions: a semimechanistic model incorporating propagule pressure and environmental factors. Am Nat 2003; 162: 713-24.

[47] Santos A. Vegetación y flora de La Palma. Santa Cruz de Tenerife: Ed. Interinsular Canaria S.A 1983.

[48] Hulme P. Beyond control: wider implications for the management of biological invasions. J Appl Ecol 2006; 43: 835-47. 